\title{
Three-year analysis to determine prognostic factors affecting success in single-dose methotrexate treatment: a single-center experience
}

\author{
Gökçe Turan', Pınar Yalçın Bahat', İbrahim Polat ${ }^{2}$ \\ 'Gynecology and Obstetrics Clinic, Kirıkhan State Hospital, Hatay, Turkey \\ ${ }^{2}$ Gynecology and Obstetrics Department, Kanuni Sultan Siileyman Training and Research Hospital, Health Sciences University, İstanbul, Turkey
}

\begin{abstract}
Objective: Our aim is to investigate the factors affecting treatment outcomes and treatment success in cases who received methotrexate for the diagnosis of ectopic pregnancy.

Methods: A total of 221 patients who admitted to Gynecology and Obstetrics Department of Kanuni Sultan Süleyman Training and Research Hospital at Health Sciences University between January 2015 and January 2018 and underwent single-dose methotrexate treatment were separated into two groups which were successful and unsuccessful. Potential demographic, clinical and laboratory results which may affect the success were compared retrospectively.

Results: The success rate after methotrexate treatment was found $76.9 \%$. In the unsuccessful group, serum $\beta$-hCG values were significantly higher than the successful group (serum $\beta$-hCG values of successful group: $2301.61 \pm 385.9 \mathrm{mIU} / \mathrm{ml}$, and serum $\beta$-hCG values of unsuccessful group: $5459.9 \pm 1255.3 \mathrm{mIU} / \mathrm{ml} ; \mathrm{p}<0.05$ ).

Conclusion: In selected cases, single-dose methotrexate treatment is an effective alternative method for ectopic pregnancy treatment compared to surgery. $\beta$-hCG levels are significant criteria for treatment success.
\end{abstract}

Keywords: Ectopic pregnancy, single-dose methotrexate treatment, $\beta$-hCG.

\section{Introduction}

Ectopic pregnancy is defined as the condition where fertilized ovum implants mostly in Fallopian tubes, and anywhere except the uterine cavity. ${ }^{[1]}$ In recent years, the diagnosis of ectopic pregnancy can be established

\section{Özet: Tek doz metotreksat tedavisinde başarıyı etkileyen prognostik faktörlerin belirlenmesinde 3 yıllık analiz: Tek merkez deneyimi}

Amaç: Amacımız ektopik gebelik tanısıyla metotreksat uygulanan olguların tedavi sonuçlarını ve tedavi başarısını etkileyen faktörleri incelemektir.

Yöntem: Ocak 2015 ile Ocak 2018 arasında Sağlık Bilimleri Üniversitesi İstanbul Kanuni Sultan Süleyman Eğitim ve Araştırma Hastanesi Kadın Hastalıkları ve Doğum Kliniği'ne başvurup tek doz metotreksat tedavisi alan 221 hasta başarılı olan ve olmayan diye iki alt gruba ayrıldı. Başarıyı etkileyebilecek olası demografik, klinik ve laboratuvar bulguları retrospektif olarak karşılaştırıld1.

Bulgular: Metotreksat tedavisi sonrası başarı oranı \%76.9 olarak bulundu. Başarısız olan grupta serum $\beta$-hCG değerleri başarılı olan gruba göre anlamlı olarak yüksek bulunmuștur (başarılı olan grubun $\beta$-hCG değeri: $2301.61 \pm 385.9 \mathrm{mIU} / \mathrm{ml}$, başarısız olan grubun $\beta$-hCG değeri: $5459.9 \pm 1255.3 \mathrm{mIU} / \mathrm{ml} ; \mathrm{p}<0.05$ ).

Sonuç: Tek doz metotreksat tedavisi seçilmiş olgularda ektopik gebelik tedavisinde cerrahiye alternatif etkili bir yöntemdir. $\beta$ hCG seviyesi tedavi başarısında önemli bir kriterdir.

Anahtar sözcükler: Ektopik gebelik, tek doz metotreksat tedavisi, $\beta$-hCG.

more early with the increased use of transvaginal ultrasonography and $\beta$-hCG in many centers. ${ }^{[2]}$ Early diagnosis contributes to the decrease in deaths related to ectopic pregnancy and cases can be diagnosed without being ruptured in this way. ${ }^{[3]}$ In ectopic pregnancy,
Correspondence: Gökçe Turan, MD. Gynecology and Obstetrics Clinic, Kırıkhan State Hospital, Hatay, Turkey. e-mail: drgokceturan@gmail.com

Received: May 1, 2018; Accepted: August 9, 2018

Please cite this article as: Turan G, Yalçın Bahat P, Polat I. Three-year analysis to determine prognostic factors affecting success in single-dose methotrexate treatment: a single-center experience. Perinatal Journal 2018;26(2):87-91.

(C2018 Perinatal Medicine Foundation
Available online at: www.perinataljournal.com/20180262006 doi: $10.2399 /$ prn. 18.0262006 QR (Quick Response) Code:

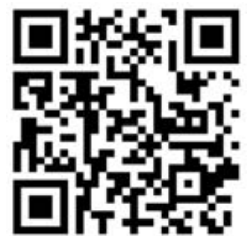


methotrexate was first used by Tanaka et al. in $1982 .{ }^{[4]}$ The success of methotrexate treatment can reach up to $92 \%$ when it is used in appropriate patients; however, since the tubal rupture risk continues despite the medical treatment and early diagnosis, it has been brought to the agenda to determine the success factors in medical treatment. ${ }^{[5]}$

The purpose of our study is to investigate the factors affecting medical treatment in patients who received ectopic pregnancy diagnosis and underwent methotrexate treatment in a three-year period in our clinic.

\section{Methods}

A total of 471 patients who received ectopic pregnancy diagnosis and treated between January 2015 and January 2018 at the Gynecology and Obstetrics Department of Kanuni Sultan Süleyman Training and Research Hospital of Health Sciences University were reviewed retrospectively. Of the recorded patients, those underwent surgical procedure were excluded from the study. Two hundred and twenty one patients who were suitable for single-dose methotrexate treatment were included in the study. Before the treatment, blood types, complete blood counts, liver function tests, and creatinine and blood urea nitrogen values of all patients were checked to determine conditions preventing methotrexate treatment. The patients were informed about methotrexate treatment and the informed consents of all patients were received. The cases who were stable hemodynamically, appropriate for follow-up after treatment, had ectopic focus sizes below $4 \mathrm{~cm}$, were not ruptured and had no fetal cardiac activity were considered suitable for methotrexate treatment and they were administered $50 \mathrm{mg} / \mathrm{m}^{2}$ intramuscular single-dose methotrexate. After the administration, $\beta$-hCG values repeated on 4th and 7 th day when MTX dose was administered. When there was a decrease for more than $15 \%$ between 4 th and 7 th days, all cases were followed up weekly until their $\beta$-hCG values decreased below $5 \mathrm{IU} / \mathrm{ml}$, and these cases were considered successful for the methotrexate treatment. However, the cases who did not have a decrease more than $15 \%$ between 4 th and 7 th days, the cases with tubal rupture and hemodynamic instability, and the cases who received a second dose of methotrexate were considered to be unsuccessful cases.
In the beginning, 221 patients who underwent methotrexate treatment were separated into 2 groups, as the group with successful results for medical treatment and the group with unsuccessful results for medical treatment.

The patients in both groups were compared by reviewing retrospectively in terms of age, gravida, parity, abortion, curettage, risk factors for ectopic pregnancy, and $\beta$-hCG values in the beginning and during the medical treatment.

Statistical Package for Social Sciences 20.0 (SPSS Inc., Chicago, IL, USA) was used for the statistical analysis of the study. Data distribution was evaluated by Kolmogorov-Smirnov test. In addition to descriptive statistical methods (mean, standard deviation) for the analysis of the data with normal distribution, independent t-test was also used for pairwise comparison. The significance level of the results was considered $\mathrm{p}<0.05$.

\section{Results}

The mean age of the patients was $32.33 \pm 5.5$ years, week of gestation was $6.61 \pm 1.54$, gravida was $2.9 \pm 1.6$, parity was $1.2 \pm 1.1$, curettage was $0.1 \pm 0.4$, and abortion was $0.5 \pm 0.9$ (Table 1). While single-dose methotrexate treatment was successful in $170(76.9 \%)$ out of 221 patients, it was unsuccessful in $51(23.07 \%)$ patients. Of 51 patients in the group with unsuccessful results for methotrexate treatment, laparoscopic salpingectomy was performed in 20 patients, salpingectomy by laparotomy in 10 patients and second-dose methotrexate was administered to 21 patients. Demographic, clinical and laboratory data of both groups are given in Table 2. No significant difference was found between two groups in terms of age, gravida, parity, hemoglobin and hematocrit levels. Serum $\beta$-hCG values on the day that methotrexate was administered $(\mathrm{p}<0.05)$, and

Table 1. The demographic characteristics of the patients who underwent single-dose methotrexate treatment.

\begin{tabular}{lc} 
& Number of patients $(\mathbf{n}=\mathbf{2 2 1})$ \\
Age & $32.33 \pm 5.5$ \\
Gravida & $2.9 \pm 1.6$ \\
Parity & $1.2 \pm 1.1$ \\
Abortion & $0.5 \pm 0.9$ \\
Curettage & $0.1 \pm 0.4$ \\
Week of gestation at admission & $6.61 \pm 1.54$ \\
\hline
\end{tabular}


Table 2. The comparison of two groups in terms of demographic, clinical and laboratory data.

\begin{tabular}{|c|c|c|c|}
\hline & Successful $(n=170)$ & Unsuccessful $(n=51)$ & p-value \\
\hline Age & $32.42 \pm 5.79$ & $32.01 \pm 4.67$ & 0.645 \\
\hline Gravida & $2.98 \pm 1.65$ & $2.72 \pm 1.31$ & 0.300 \\
\hline Parity & $1.18 \pm 1.08$ & $1.17 \pm 1.05$ & 0.973 \\
\hline Abortion & $0.58 \pm 1.01$ & $0.31 \pm 0.54$ & 0.071 \\
\hline Curettage & $0.11 \pm 0.47$ & $0.09 \pm 0.3$ & 0.780 \\
\hline Week of gestation at admission & $6.49 \pm 1.56$ & $7 \pm 1.41$ & 0.040 \\
\hline Hemoglobin value at admission (mg/dl) & $11.78 \pm 1.6$ & $11.47 \pm 1.75$ & 0.228 \\
\hline Hemoglobin value at hospital discharge (mg/dl) & $11.88 \pm 1.12$ & $10.41 \pm 1.22$ & 0.358 \\
\hline$\beta$-hCG value on the first day of methotrexate $(\mathrm{mlU} / \mathrm{ml})$ & $2301.61 \pm 385.9$ & $5459.9 \pm 1255.3$ & 0.005 \\
\hline$\beta$-hCG value on the 4 th day of methotrexate $(\mathrm{mlU} / \mathrm{ml})$ & $1958.2 \pm 281.9$ & $5844.1 \pm 1247.3$ & $<0.001$ \\
\hline$\beta$-hCG value on the 7 th day of methotrexate $(\mathrm{mlU} / \mathrm{ml})$ & $1226.1 \pm 200.3$ & $5584.6 \pm 1253.2$ & $<0.001$ \\
\hline Admission complaints & & & 0.498 \\
\hline Vaginal bleeding & $30(13.6 \%)$ & $8(3.6 \%)$ & \\
\hline Stomachache & $89(40.3 \%)$ & $23(10.4 \%)$ & \\
\hline Inguinal pain & $45(20.4 \%)$ & $19(8.6 \%)$ & \\
\hline Menstrual delay & $6(2.7 \%)$ & $1(0.5 \%)$ & \\
\hline
\end{tabular}

$\mathrm{p}<0.05$ : statistically significant.

$\beta$-hCG values on 4th and 7 th days was significantly higher in the group which was unsuccessful for singledose methotrexate $(\mathrm{p}<0.001)$. First day methotrexate $\beta$ hCG value was $5459.9 \pm 1255.3 \mathrm{mIU} / \mathrm{ml}$ in the unsuccessful group while it was $2301.61 \pm 385.9 \mathrm{mIU} / \mathrm{ml}$ in the successful group.

When admission complaints were analyzed, there was no significant difference between two groups in terms of affecting the success of methotrexate treatment $(\mathrm{p}=0.498)$.

In Table 3, the groups which were successful and unsuccessful in methotrexate treatment were compared in terms of ectopic pregnancy risk factors, and the patients who had ectopic pregnancy previously and received methotrexate for risk factors and underwent surgical procedures were included. No difference was found in terms of parameters evaluated in both groups $(\mathrm{p}=0.207)$.

When the patients were analyzed according to the location of ectopic focus, no difference was found between two groups in terms of predicting the success of methotrexate treatment according to the location of ectopic focus $(\mathrm{p}=0.144)$ (Table 4$)$.

\section{Discussion}

Ectopic pregnancy is one of the most important reasons for maternal mortality and morbidity in the first
Table 3. Risk factors for ectopic pregnancy in both groups.

\begin{tabular}{lccc} 
& $\begin{array}{c}\text { Successful } \\
(\mathbf{n}=\mathbf{1 7 0})\end{array}$ & $\begin{array}{c}\text { Unsuccessful } \\
(\mathbf{n}=\mathbf{5 1})\end{array}$ & $\begin{array}{c}\mathbf{p}- \\
\text { value }\end{array}$ \\
Risk factor & & & 0.207 \\
Previous ectopic pregnancy & $10(4.5 \%)$ & $5(2.2 \%)$ & \\
Previous tubal surgery & $6(2.7 \%)$ & $3(1.3 \%)$ & \\
None & $154(69.6 \%)$ & $43(19.4 \%)$ & \\
\hline
\end{tabular}

$p<0.05$ : statistically significant.

Table 4. Ectopic focus locations in both groups.

\begin{tabular}{lccc} 
& $\begin{array}{c}\text { Successful } \\
(\mathbf{n}=\mathbf{1 7 0})\end{array}$ & $\begin{array}{c}\text { Unsuccessful } \\
(\mathbf{n}=\mathbf{5 1 )}\end{array}$ & $\begin{array}{c}\mathbf{p}- \\
\text { value }\end{array}$ \\
\hline Location & $163(73.8 \%)$ & $46(20.8 \%)$ & 0.144 \\
Tubal & $6(2.7 \%)$ & $3(1.4 \%)$ & \\
Cornual & $1(0.5 \%)$ & $2(0.9 \%)$ & \\
Scar & 0 & 0 & \\
Ovarian & 0 & 0 & \\
Cervical & 0 & \\
\hline
\end{tabular}

$p<0.05$ : statistically significant.

trimester. ${ }^{[6]}$ With the increased use of ultrasonography and $\beta$-hCG values, the diagnoses can be established at an earlier period without any rupture development, and therefore medical treatment option can be offered. Since methotrexate use is effective and safe, the medical treatment decreased the frequency of surgical pro- 
cedure ${ }^{[6]}$ Ectopic pregnancy is seen mostly in oviducts; however, ectopic pregnancies can also be observed in locations such as cervical area, cesarean scar line, ovary and abdomen. In our study, we did not observe any cervical and ovarian pregnancy in patients who received single-dose methotrexate; the ectopic focus was mostly in the ampulla which is consistent with the literature, and we observed in 207 (94.6\%) patients that ectopic focus location was ampulla. However, the location of ectopic focus was not significant to predict methotrexate success.

In the ectopic pregnancies, different regimes are used for methotrexate treatment. They are single- or multiple-dose, local or systemic administrations. However, considering the ease of use and treatment cost, single-dose regime is preferred more frequently. ${ }^{[7]}$ In our study, we analyzed the patients who underwent single-dose methotrexate treatment.

Success rates of single-dose methotrexate administration for ectopic pregnancy reach up to $92 \% .{ }^{[8]}$ In our study, treatment success for the cases we administered single-dose methotrexate was $76.9 \%$, which was consistent with the literature.

Some studies reported the presence of low $\beta$-hCG values in cases before the treatment (mostly $<4000$ $\mathrm{IU} / \mathrm{ml}$ ), absence of fetal cardiac activity and small ectopic pregnancy mass as the factors affecting the success of methotrexate treatment. ${ }^{[9,10]}$ However, there are various studies reporting that high level of $\beta$-hCG in the beginning of treatment is the most important factor affecting treatment, which means that success rates significantly decreases as pre-treatment $\beta$-hCG level increases. ${ }^{[11,12]}$ In our study, consistent with the literature, we found that $\beta$-hCG level was higher in unsuccessful group $(5459.9 \pm 1255.3)$ compared to the successful group $(2301.61 \pm 385.9)$.

In the meta-analysis of Barnhart et al. where they reviewed 26 articles and 1327 cases, the authors found the success rate $92.7 \%$ for multiple-dose regime and $88.1 \%$ for single-dose regime while total success rate $89 \%$ for methotrexate treatment. ${ }^{[8]}$

Uğurlucan et al. analyzed 83 cases who underwent single-dose methotrexate treatment, and they achieved success in $65(78.3 \%)$ cases while the treatment was unsuccessful in 18 (21.7\%) cases. At the end of study, the authors observed that the rates of unsuccessful cases increase where $\beta$-hCG levels are above 2000 $\mathrm{mIU} / \mathrm{ml}$ and ectopic focus size is above $30 \mathrm{~mm} .{ }^{[13]} \mathrm{In}$ our study, we also found that high $\beta$-hCG value is one of the factors affecting the success rates negatively. However, we did not take ectopic focus size into consideration unlike the study of Uğurlucan et al.

Aka et al. retrospectively analyzed 65 patients who received single-dose methotrexate, and they found that $86.2 \%(n=56)$ of the patients were responsive to the methotrexate treatment while $13.8 \%(\mathrm{n}=9)$ of them were unresponsive. While the mean, hCG value of the responsive group was $1435.68 \pm 1186.1$, it was $2960.11 \pm$ 1626.55 in the unresponsive group. There was no statistically significant difference between two groups in terms of $\beta$-hCG values. ${ }^{[14]}$ Similarly, Lispcomb et al. found that $\beta$-hCG levels were significantly high in the group which had unsuccessful results for single-dose methotrexate treatment, and they concluded that pretreatment $\beta$-hCG values are the best prognostic data to predict the success of methotrexate treatment. ${ }^{[15]}$

Yıldırım et al. retrospectively analyzed 85 ectopic pregnancy cases who were treated with methotrexate, and found that the success rate was $88.2 \%$ after methotrexate treatment; unlike the literature, the authors found no significant difference between the cases responsive to the treatment and the cases unresponsive to the treatment in terms of pre-treatment $\beta$ hCG values, mass sizes and endometrial thickness. ${ }^{[16]} \mathrm{In}$ our study, we considered that high $\beta$-hCG values were risk factors for the unsuccessful treatment, but we did not evaluate the endometrial thickness.

In the study of Yildiz et al., the authors retrospectively analyzed 351 patients who were established the diagnosis of ectopic pregnancy and received singledose methotrexate, and they found that 240 (68.3\%) of 351 patients were successfully treated with single-dose methotrexate while the treatments of 111 (31.7\%) patients with single-dose methotrexate were unsuccessful. Mean $\beta$-hCG value was $1265 \mathrm{mIU} / \mathrm{ml}$ in the group which underwent successful single-dose methotrexate treatment while it was $5751 \mathrm{mIU} / \mathrm{ml}$ in the unsuccessful group. ${ }^{[17]}$

Kıliç et al. included 99 patients who underwent single-dose methotrexate treatment in the study, and the single-dose methotrexate treatment was successful in $67(67.6 \%)$ patients. Serum $\beta$-hCG value was 3562 $\mathrm{mIU} / \mathrm{ml}$ in the unsuccessful group and $819 \mathrm{mIU} / \mathrm{ml}$ in 
the successful group, and the authors found that serum $\beta$-hCG values were significantly higher in the unsuccessful group than the successful group. ${ }^{[18]}$

Pulatoğlu et al. analyzed 101 cases with tubal ectopic pregnancy diagnosis who underwent singledose methotrexate treatment, and they found the success rate of methotrexate treatment $77.2 \% \quad(n=79)$. They concluded that the patients with $\beta$-hCG levels below $1362 \mathrm{mIU} / \mathrm{mL}$ are appropriate candidates for methotrexate treatment. ${ }^{[19]}$

\section{Conclusion}

Methotrexate treatment is safe and effective for ectopic pregnancy, and it is an effective alternative method for the treatment of ectopic pregnancy in selected cases compared to the surgical procedure. $\beta$-hCG levels are significant criteria for treatment success.

Conflicts of Interest: No conflicts declared.

\section{References}

1. Hallatt JG. Repeat ectopic pregnancy: a study of 123 consecutive cases. Am J Obstet Gynecol 1975;122:520-4.

2. Coste J, Bouyer J, Ughetto S, Gerbaud L, Fernandez H, Pouly J, L Job-Spira N. Ectopic pregnancy is again on the increase. Recent trends in the incidence of ectopic pregnancies in France (1992-2002). Hum Reprod 2004;19:2014-8.

3. Luciano AA, Roy G, Solima E. Ectopic pregnancy from surgical emergency to medical management. Ann N Y Acad Sci 2001;943:235-54.

4. Tanaka T, Hayashi H, Kutsuzawa T, Fujimoto S, Ichinoe K. Treatment of interstitial ectopic pregnancy with methotrexate: report of a successful case. Fertil Steril 1982;37:851-2.

5. Lipscomb GH, McCord ML, Stovall TG, Huff G, Portera SG, Ling FW. Predictors of success of methotrexate treatment in women with tubal ectopic pregnancies. N Engl J Med 1999;341:1974-8.

6. Centers for Disease Control and Prevention (CDC). Ectopic pregnancy - United States, 1990-1992. JAMA 1995;273:533.

7. Berg CJ, Chang J, Callaghan WM, Whitehead SJ. Pregnancyrelated mortality in the United States, 1991-1997. Obstet Gynecol 2003;101:289-96.

8. Barnhart KT, Gosman G, Ashby R, Sammel M. The medical management of ectopic pregnancy: a meta-analysis comparing "single dose" and "multidose" regimens. Obstet Gynecol 2003; 101:778-84.

9. Tawfig A, Agomeya AF, Claman P. Predictors of treatment failure for ectopic pregnancy treated with single-dose methotrexate. Fertil Steril 2000;174:877-80.

10. da Costa Soares R, Elito J Jr, Han KK, Camano L. Endometrial thickness as an orienting factor for the medical treatment of unruptured tubal pregnancy. Acta Obstet Gynecol Scand 2004;83:289-92.

11. Corsan G, H, Karacan M, Qasim S, Bohrer M, K Ransom, MX, Kemmann E. Identification of hormonal parameters for successful systemic single-dose methotrexate therapy in ectopic pregnancy. Hum Reprod 1995;10:2719-22.

12. Nazac, A, Gervaise A, Bouyer J, de Tayrac R, Capella-Allouc S, Fernandez H. Predictors of success in methotrexate treatment of women with unruptured tubal pregnancies. Ultrasound Obstet Gynecol 2003;21:181-5.

13. Uğurlucan, F G, İyibozkurt A C, Çetin C, Nehir A, Akhan S. Ektopik gebelik tedavisinde metotreksat kullanımı: tedavi sonucunu etkileyen faktörler. Ege Tip Dergisi 2013;52:199_ 204.

14. Aka N, Karaca K. Ektopik gebelik tedavisinde intramuskuler tek doz metotreksat protokolünün etkinliği. Haydarpaşa Numune Eğitim ve Araştırma Hastanesi Tip Dergisi 2015;55: $165-9$.

15. Lipscomb, GH, Puckett, K.J, Bran, D, Ling, FW. Management of separation pain after single-dose methotrexate therapy for ectopic pregnancy. Obstet Gynecol 1999;93:590-3.

16. Yildirim G, Güngördük K, Aktaş F N, Ülker V, Sudolmuş S, Tekirdă A.İ. Ektopik gebelik tedavisinde tek doz metotreksat: 85 olgunun değerlendirilmesi. Turkish Journal of Obstetrics and Gynecology 2007;4:68-71.

17. Yıldız A, Doğan O. Ektopik gebeliklerde tek doz metotreksat tedavisinin etkinliğinin değerlendirilmesi: 5 yıllık deneyim. Kafkas Tip Bilimleri Dergisi 2017;7:188-92.

18. Kılıç B Ş, Tüten A, Öncül M, Açıkgöz AS, Öcal PK. Identifying prognostic factors which affect the success of ectopic pregnancy treatment with a single dose methotrexate. Turkish Journal of Obstetrics and Gynecology 2014;11: 84-7.

19. Pulatoğlu Ç, Doğan O, Başbuğ A, Ellibeş Kaya A, Yıldız A, Temizkan O. Predictive factors of methotrexate treatment success in ectopic pregnancy: a single tertiary center study. North Clin Istanb 2018 [Ahead of print NCI-04900]. 